\title{
O IMAGINÁRIO DO SAGRADO A PARTIR DAS ESCULTURAS DO PAREDÃO EM ORLEANS-SC: A ARTE DO SAGRADO E O SAGRADO NA ARTE DE ZÉ DIABO
}

\author{
HELOISA JUNCKLAUS PREIS MORAES ${ }^{1}$, LUIZA LIENE BRESSAN ${ }^{2}$, \\ ANA CAROLINE VOLTOLINI FERNANDES ${ }^{3}$
}

\author{
Universidade do Sul de Santa Catarina \\ Programa de Pós-Graduação em Ciências da Linguagem \\ Av. José Acácio Moreira, 787 - 88704-900 - Tubarão - SC - Brasil \\ heloisapreis@hotmail.com, luizalbceyahoo.com.br, \\ anacaroline.voltoliniehotmail.com
}

\begin{abstract}
Resumo. Este estudo tem por objetivo discutir as relações entre imaginário, sagrado, obra de arte e pertencimento. A partir das "esculturas do paredão" do artista Zé Diabo procuramos estudar as imagens por ele esculpidas em rocha viva no município de Orleans, Santa Catarina. Para atender ao objetivo traçado, buscamos refletir sobre o conceito de arte e construir a relação existente entre imaginário, sagrado e de que forma se constrói as teias que nos une e que nomeamos de pertencimento. Como percurso metodológico nos guiamos pelos caminhos da Hermenêutica Simbólica, tendo o conceito de trajeto antropológico como guia de compreensão simbólica.
\end{abstract}

Palavras-chave: imaginário; sagrado; arte; esculturas no paredão; pertencimento.

\begin{abstract}
This study aims to discuss the relationships between imaginary, sacred, work of art and belonging. From Zé Diabo's "wall-stone" sculptures we tried to study the images he sculpted in living rock in Orleans, Santa Catarina. In order to meet the goal set, we seek to reflect on the concept of art and build the relationship between imaginary and sacred and how the webs that unite us and which we name as belonging. As a methodological course, we are guided by the paths of Symbolic Hermeneutics, having the concept of an anthropological path as a guide to symbolic understanding.
\end{abstract}

Keywords: imaginary; sacred; art; sculptures in the wall; belonging.

\footnotetext{
${ }^{1}$ Doutora em Comunicação Social pela Pontifícia Universidade Católica do Rio Grande do Sul. Docente na graduação do Curso de Comunicação Social e no Programa de Pós-Graduação em Ciências da Linguagem da Universidade do Sul de Santa Catarina.

2 Doutoranda em Ciências da Linguagem pelo PPGCL/Unisul.

${ }^{3}$ Mestranda em Ciências da Linguagem pelo PPGCL/Unisul.
} 


\section{DA BELEZA À ARTE: REFLEXÕES NECESSÁRIAS}

O ser humano, como um ser simbólico, sempre buscou imagens para (re) significar sua existência. Dessa forma, "consideramos que todo esse pensamento do homo sapiens traz, na sua essência, imagens que geram ideias e permitem a construção do conhecimento, o que influencia diretamente nas suas práticas sociais" (LEAL; LINS, 2017, p. 42). Assim, sob o viés da antropologia do imaginário, ancorado nos postulados de Durand $(1996 ; 2012)$ e outros estudiosos, iniciamos nossa reflexão sobre os fios que se enredam, quando estudamos as manifestações do sagrado na escultura sacra, que é o objeto aqui estudado.

Isso porque, o imaginário enquanto conjunto e relação de imagens que constituem o capital pensado do homo sapiens se apresenta como o grande denominador fundamental em que se encontram todas as criações do pensamento humano (DURAND, 2012, p. 12), inclusive as imagens sacras, pois estas constituem manifestações simbólicas da religiosidade de determinada civilização e, por consequência, do indivíduo.

Ao focarmos o estudo na teoria do imaginário é relevante pensar o papel da imaginação e dos símbolos que expressam o sagrado. Cabe lembrar as palavras de Durand (2012, p.20) ao dizer que "pensamento ocidental e a filosofia francesa têm por constante desvalorizar ontologicamente a imagem e psicologicamente a função da imaginação". Ora, sem a potência imaginativa, o ser humano não se renovaria e nem venceria a face maligna do tempo que a tudo devora. Assim, a função simbólica da estrutura cultural se encontra em autores que sejam grandes espíritos. Em outras palavras,

alguns escritores e artistas mergulham neste húmus inconsciente e espontâneo para nele se alimentarem e para a ele doarem sua imaginação renovadora e o seu imaginário próprio. São os que dão vida, alento e calor a seu povo; são os que descobrem todos os dias a riqueza inesgotável do imaginário que ele trouxe da sua viagem pelo tempo: mitos, arquétipos, modelos, uma vivência do sagrado, uma vivência dos padecimentos do sagrado, o sentido do seu "estar no mundo" para lá de cada época e, como enfim, assumiram a herança de um imaginário, não para o receber estaticamente, mas para o dinamizar e renovar. (QUADROS, 1992, p. 11)

A religiosidade do artista catarinsense Zé Diabo, como veremos adiante, está imortalizada por sua arte, que emerge da rocha e pereniza a crença do artista e nos faz pensar, tal como Durand afirmou que

o imaginário de cada povo é o seu Universal, exatamente na medida que possa revelar a sua originalidade virtual e atual, e transformar as formas estruturais extintas ou arrefecidas em arquétipos dinâmicos, em sujeitos que serão criadores de civilização, não quando se fechem em si próprios e sobre seu passado, mas quando se abram para os mais altos horizontes futuros, pensados que sejam por filosofia criacionista do espírito. (DURAND apud QUADROS, 1992, p. 12)

Assim como o respirar, o caminhar, o amar e o trabalhar, a criação artística é inerente ao ser humano e é tão velha como a própria humanidade. Desde a tradição grega, a problematização acerca de uma conceituação para Arte rende longas reflexões. $O$ conceito de mimesis é, para a compreensão da Poética de Aristóteles, um termo essencial 
que sustenta suas considerações a respeito da Arte poética, termo este que designa, em sua acepção mais geral, imitação.

Este conceito também foi longamente discutido por Platão, no entanto é com Aristóteles que se definem as significações mais ideais do termo, escapando da ideia platônica de "cópia". Dessa forma, Aristóteles transcende seu mestre e já no início de sua obra Poética define o que para ele seria o ato da imitação ao afirmar que

a imitação (mimese) de uma ação é o mito (fábula)... A parte mais importante é a da organização dos fatos, pois a tragédia é a imitação, não de homens, mas de ações, da vida, da felicidade e da infelicidade (pois a infelicidade resulta também da atividade) ... Daí resulta serem os atos e a fábula a finalidade da tragédia. Sem ação, não há tragédia. (ARISTÓTELES, 1959, p. 299)

Para ele, há na espécie humana a tendência natural para o imitar, aliás, isto o distingue de outros seres da natureza, pois entre todos os outros ele é o mais verdadeiro. A mimesis é a imitação da ação. Há uma separação entre os indivíduos que praticam as artes miméticas e esta divisão é estabelecida conforme a qualidade ou modo dos que representam a imitação.

A partir destas reflexões clássicas sobre o conceito de arte, muitos foram os estudiosos que se debruçaram a tecer redes plurissignificativas que envolvem a conceituação do termo. A evolução do conceito de da arte está ligada, em linhas gerais, à evolução da humanidade e do desenvolvimento das tecnologias, próprias de cada período evolutivo. Azevedo Júnior $(2007$, p.7) acrescenta que a "arte é uma experiência humana de conhecimento estético que transmite e expressa ideias e emoções" e acrescenta, ainda, que cada sociedade apresenta variados estilos de fazer arte, pois cada uma apresenta seus próprios valores, sejam eles morais, religiosos e artísticos, cada região tem sua cultura, e, portanto, a arte se manifesta de acordo com a cultura que se impregna o fazer do artista (AZEVEDO JÚNIOR, 2007). cabe à arte o

Assim, refletir sobre arte é também pensar na sociedade, pois conforme Fischer,

papel de clarificação das relações sociais, ao papel de iluminação dos homens em sociedades que se tornavam opacas, ao papel de ajudar o homem a reconhecer e transformar a realidade social. Uma sociedade altamente complexificada, com suas relações e contradições sociais multiplicadas, já não pode ser representada à maneira dos mitos. (FISCHER, 1983, p. 01)

Na verdade, cabe à arte incitar a ação, sendo necessária para que o homem se torne capaz de conhecer e transformar o mundo em que vive (FISCHER, 1983). Ela traz a expressão dos elementos simbólicos que nos ligam à perspectiva do imaginário.

Os símbolos e mitos são pintados, esculpidos, entoados e narrados nas mais diversas culturas e "instauram-se na forma de mitologemas, isto é, uma ideia motriz que permanece na memória coletiva das sociedades, essencialmente, pela herança cultural, pelos modos de vida, pela língua e por outros fatores determinantes" (GALLINA; ORMEZZANO, 2017, p. 258). 
Isso porque, as imagens de deuses e as representações de objetos considerados sagrados só são passíveis de serem compreendidos através de uma consciência simbólica, trazendo-se a surrealidade invisível a uma forma visível. Tratar-se-ia de uma forma de desvelamento de realidades que não poderiam ser reduzidas a ficções ou alucinações (WUNENBURGER, 2007, p. 24).

No caso do objeto em análise, o relato mítico cristão é conduzido à esfera visível através das esculturas do artista Zé Diabo, as quais passam a reger o imaginário local da cidade de Orleans, pois nas palavras de Pitta (2005, p. 60), o "mito irriga a história, ele dá um sentido, uma estrutura, ao que seria apenas uma acumulação insignificante de eventos. Então o sentido está na relação, na complexidade, e não na única sucessão diacrônica." As esculturas produzidas pelo artista Zé Diabo manifestam a necessidade humana de organizar seu viver diante do desconhecido, diante do caos, dando significação à sua existência e ao mundo, pois ao esculpir as passagens míticas cristãs, o referido artista sacralizou o espaço que até então era profano, deu forma ao que até então era informe.

Na geografia mítica, o espaço sagrado é o espaço real por excelência, pois, tal como se provou recentemente, para o mundo arcaico o mito é real porque ele relata as manifestações da verdadeira realidade: o sagrado. É em tal espaço que se está diretamente em contato com o sagrado - seja este materializado em certos objetos (tchuringas, representações da divindade, etc.) ou manifestado nos símbolos hierocósmicos (Pilar do Mundo, Arvore Cósmica, etc.). (ELIADE, 1952, p. 39-40)

As esculturas produzidas pelo artista Zé Diabo teriam, assim, a finalidade de sacralizar o espaço geográfico em que estavam inseridas e dar um sentimento de pertença tanto para o artista, quanto para os moradores da cidade de Orleans, dado que "os símbolos, os mitos e os ritos revelam sempre uma situação-histórica: situação limite quer dizer: aquela que o homem descobre ao tomar consciência do seu lugar no Universo" (ELIADE, 1952, p. 34), função essa do imaginário do sagrado, que busca eufemizar a angústia existencial do homem em relação à sua finitude.

Nesse sentido, Zé Diabo desenvolveu durante seu viver o que Campbell denominou de mitologia "criativa", que ocorre quando

o indivíduo tem uma experiência própria - de ordem, horror, beleza, ou até de mera alegria - que procura transmitir mediante sinais; e se sua vivência teve alguma profundidade e significado, sua comunicação terá o valor e força de um mito vivo - obviamente para aqueles que a recebam e reagem a ela por conta própria, com empatia, sem imposições. (CAMPBELL, 2010, p. 20)

Assim, temos como objeto de análise as esculturas do paredão de Orleans, Santa Catarina, pensadas a partir de um imaginário do sagrado, mitológico, recorrente e pregnante; Estabelece-se aí uma relação de identificação e pertencimento local em função da arte do sagrado bem como do sagrado na arte, fator de potência simbólica, já que os símbolos, "por estarem re-injetadas num conjunto sociocultural, aumentam as existências e a qualidade de informação da sociedade e o mito retorna reatualizado, aperfeiçoando em dada sociedade os processos de identificação e sentimento de pertença" (MORAES; BRESSAN, 2017, p. 143). Por isso, já em outros estudos, afirmamos que "são trajetos em 
constante retroalimentação e que vão se fazendo presentes em todas as culturas, dando ao mito esse dinamismo que não cessa" (MORAES; BRESSAN, 2017, p. 143).

\section{MÉTODO E TÉCNICAS}

As esculturas são tidas como textos culturais sobre às quais trazemos para análise por meio da Hermenêutica Simbólica, já que entendemos a recorrência simbólica das imagens esculpidas na pedra como uma atividade da imaginação simbólica. Estas esculturas inserem-se no mundo da dimensão cultural que diz respeito às formas de representação criadas e difundidas como o patrimônio cognitivo e criativo do local, ou seja, obras ou referências artísticas, tradicionais e simbólicas com as quais os indivíduos se identificam.

É Cassirer, ao nomear o homo symbolicum, que nos afirma que o símbolo tem como característica essencial o sentido. As formas e a cultura do homem, bem como o conhecimento, são de natureza simbólica. Assim, podemos inferir que suas relações sociais são marcadamente experimentadas no campo simbólico.

Dessa forma, as imagens sagradas esculpidas em rocha viva pelo artista Zé Diabo se constituem como narrativas que podem ser interpretadas por meio da Hermenêutica Simbólica na tentativa, tal como propôs Husserl, voltar-se às coisas mesmas (SILVA; GOMES, 2013). Aqui, estas coisas mesmas são as esculturas e sua potência simbólica para discutir a arte do sagrado e o sagrado na arte.

Nestas trajetórias do significado ao sentido, tomamos como principal categoria metodológica o trajeto antropológico de Durand (2012). Ou seja, "a incessante troca que existe ao nível do imaginário entre as pulsões subjetivas e assimiladoras as intimações objetivas que emanam do meio cósmico e social. [...] gênese recíproca que oscila do gesto pulsional ao meio material e social e vice-versa" (DURAND, 2012, p. 41). É este trajeto que nos dá a pertinência da compreensibilidade simbólica, "instrumento mediúnico do sagrado" (SILVA; GOMES, 2013) entre as imagens arquetipais, simbólicas e mitológicas do artista e o sentido social de identificação e pertencimento social que assume, já que o universo humano é o universo simbólico.

Panofsky (1979) estabelece uma diferença entre os objetos estéticos e os objetos naturais, afirmando que o cientista ao trabalhar com os fenômenos naturais pode analisálos de pronto. Já o humanista (que trabalha com os objetos estéticos) o faz, procurando interpretar as ações e criações humanas e precisa se empenhar em um processo mental de caráter sintético e subjetivo, a fim de que os símbolos produzidos tenham significado. Assim, podemos dizer que a partir dos símbolos, podemos estudar uma hermenêutica que no sentido ricoueriano pode ser assim definida como "a teoria das operações da compreensão em sua relação com a interpretação dos textos" (RICOUER, 2013, p. 23), pois na percepção de seu vazio existencial, o ser humano constrói símbolos como uma linguagem fundamental que, a partir de sentido literal, aponta para o segundo sentido que diz respeito a outra realidade que se mostra existencialmente mais importante e fundante.

Neste caso, as esculturas do paredão criam este sentido outro que aos olhos do expectador apontam outras interpretações, por se conectaram com aspectos religiosos. Aqui, o simbolismo é extremamente relevante como manifestação da experiência religiosa, estabelece a mediação do humano que expressa a crença na divindade, posto 
que a experiência do sagrado não se objetiva. Assim, pensar uma hermenêutica simbólica com a qual se possa interpretar as esculturas sacras de Zé Diabo no paredão está relacionado ao que Ricouer (1991, p. 122) define como interpretar.

O que se deve, de fato, interpretar num texto é uma proposta de mundo, de um mundo tal que eu possa habitar e nele projetar um dos meus possíveis mais próprios. É aquilo que eu chamo o mundo do texto, o mundo próprio a este texto único. Ricouer (1976) ainda comenta que é na medida em que não responde ao autor que a obra responde ao sentido, afinal o leitor apenas compreende a si pela "grande digressão dos signos de humanidade depositados nas obras de cultura" Acrescenta, ainda, Paul Ricouer que "é neste sentido que os símbolos estão ligados no interior do universo sagrado: os símbolos só vêm à linguagem na medida em que os próprios elementos do mundo se tornam transparentes" (RICOEUR, 1976, p. 73).

\section{UM PINTOR/ESCULTOR: VIDA, FATOS E UM PARADOXO ${ }^{4}$}

Pensar a obra esculpida em rocha viva em Orleans, sul de Santa Catarina, é também pensar no artista que a concebeu. José Fernandes, conhecido por Zé Diabo, já constrói em seu nome e apelido uma simbologia das forças do sagrado, pois o mesmo se notabilizou pela pintura e escultura sacra. Quando questionado sobre o fato, respondia: "Zé Diabo, o artista de Deus". Zé Diabo ocupava-se do sagrado, aludindo as forças do bem e repelindo as do mal.

A afinidade com o paredão (conhecido como corte) vinha desde a infância, pois o artista criou-se às margens do trecho extinto da ferrovia Teresa Cristina. Eram frequentes as brincadeiras na região em que o leito da ferrovia foi construído. Em meio às brincadeiras de infância, seu olhar segue as pedras que desafiaram os trabalhadores na construção da estrada e nelas via as marcas deixadas por esses operários. Uma, em particular, chamava-lhe a atenção: as iniciais B.A. gravadas na pedra. Soube, posteriormente, que se tratava de homenagem a um dos trabalhadores que faleceu vítima de uma explosão de dinamites para destruir a rocha.

O primeiro contato com a pedra veio aos doze anos, quando foi ajudar o pai em uma pedreira. Começava, ali, o aprendizado de esculpir em rocha. Passado este período de trabalho árduo, começaram as atividades de pintor de paredes, para a qual se dedicou por alguns anos. A partir desta experiência profissional, iniciou a pintura de capelas pelo interior do município de Orleans. Começava, então, sua trajetória de artista. A expressão de sua arte nas igrejas iniciou com a representação de cenas religiosas do antigo e novo testamento. José Fernandes, durante 30 anos, foi pintor. Pintou várias obras em telas e em paredes de igrejas, representando temas religiosos, paisagens, retratos e autorretratos.

Nos longos anos dedicados à pintura sacra, o paredão de pedras cobertas de musgo não ficou esquecido. Era um desejo latente que começou a ganhar contornos de verdade a partir da década de 1980, quando a Fundação Educacional Barriga Verde, fundada em 1974, auxiliou no desenvolvimento de atividades culturais que objetivava a preservação e a salvaguarda do patrimônio cultural do município, afetado duramente pela cheia de 1974, que destruiu boa parte dos municípios do vale do Rio Tubarão. Na informalidade

${ }^{4}$ FERNANDES, José. Entrevista concedida à autora Luiza Liene Bressan da Costa. Orleans, 2017. 
de uma conversa com o diretor da instituição, José Fernandes manifestou seu desejo de ver o paredão de pedras modificado por um grande painel de imagens esculpidas.

Com o incentivo institucional recebido, o envolvimento de outras autoridades e o apoio do Iphan - Instituto do Patrimônio Histórico e Artístico Nacional, em 1980 iniciamse os trabalhos na rocha, reproduzindo as passagens do Antigo e Novo Testamento. Inicialmente, o artista fez um projeto para nove painéis, assim nomeados: "A Criação do Homem", "O Sacrifício de Abraão", "A Passagem do Mar Vermelho", "O Templo do Rei Salomão" e os "Os Profetas". Estes painéis têm temáticas que expressam passagens do velho testamento, compondo uma parte do projeto. Todos foram concluídos. A segunda parte retrataria cenas do Novo Testamento. "A Anunciação", "O Presépio", "A morte de Cristo", "A ressurreição de Cristo". Destes, somente o primeiro foi concluído. Um desentendimento entre o gestor municipal e o artista, em 1989, interrompe a execução do trabalho e o mesmo nunca mais foi retomado.

Uma das mais expressivas obras de arte em rocha foi bastante difundida entre os anos de 1990 e 2005. Após este período, caiu no ostracismo e musgos e mata encobriram os painéis. Durante um longo período, soluções paliativas de limpeza foram executadas, mas o paredão já não tinha a mesma potência simbólica. $\mathrm{O}$ artista entristecia-se com a situação. Então, no início de 2017, gestão municipal e Febave selam um acordo de revitalização e limpeza das esculturas. Uma equipe técnica foi criada e, em julho de 2017, os trabalhos foram concluídos. A reinauguração aconteceu em 30 de agosto, quando é comemorado o aniversário da cidade. Dias antes, o artista visitou o paredão e manifestou sua alegria ao vê-lo outra vez em sua exuberância. No entanto, antes de receber a obra oficialmente, o artista vem a óbito, em 21 de agosto de 2017.

\section{AS CRIAÇÕES ESCULPIDAS}

Todas os painéis são interpretações do artista. É a expressão de fé de sua religiosidade. O primeiro painel esculpido por Zé diabo foi "A Criação do Homem", medindo nove metros quadrados, representa a criação do Homem e do Mundo. O artista concluiu este painel em um ano. Na parte superior do painel está uma figura masculina, com os braços abertos representando Deus, e de mão espraiam-se raios de vida. Estes raios espraiados em feixes de luz criam as figuras de Adão e Eva, dando um efeito de que são nascidos deste momento de inspiração divina.

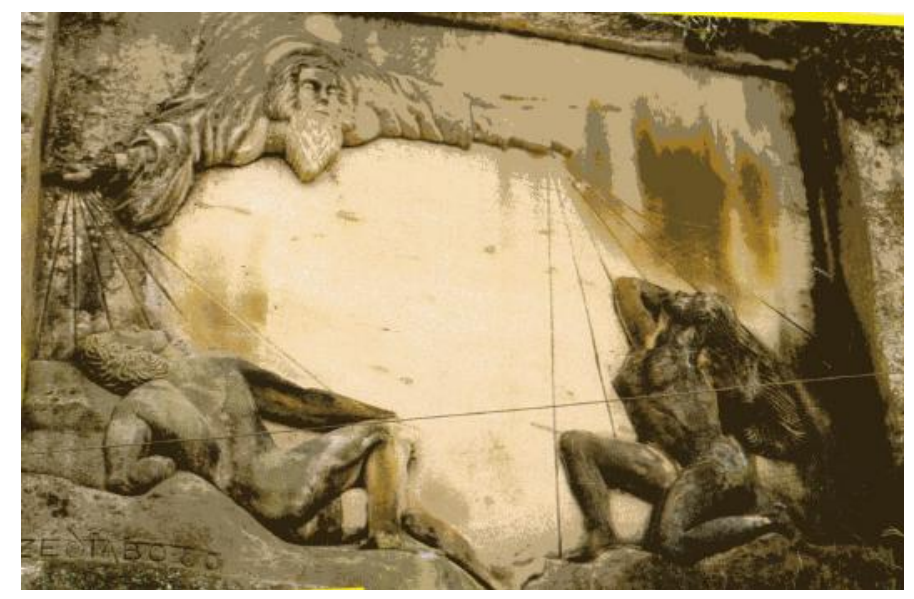

Imagem 1. Fonte: arquivo das autoras, 2017. 
É interessante observar que a luz em várias religiões, inclusive no cristianismo, está diretamente relacionada ao sagrado e rege o imaginário individual e coletivo quando se trata de representação do sagrado. Estudando a recorrência simbólica da luz, que geralmente é representada por um raio/relâmpago, pode-se verificar que ela traduz a necessidade humana de fugir do obscuro, do desconhecido, do caos, para então adentrar em um estado de maior consciência, integração e harmonia com a exterioridade. Eliade estudou as manifestações do que ele denominou "luz mística" em diversas religiões e filosofias e concluiu que esta sempre fora associada ao estado de nascimento ou renascimento, da passagem de um limiar, de um esclarecimento sobre o meio que cerca o neófito.

\begin{abstract}
A instantaneidade da iluminação espiritual foi comparada, em grande número de religiões, ao relâmpago. Mais ainda: ao brusco lampejo do raio que rasga as trevas atribui-se o valor de um misterium tremendum que, ao transfigurar o mundo, enche a alma de terror sagrado. [...] A pessoa que sobrevive à experiência do raio muda completamente; na verdade começa uma nova existência, é um homem novo. [...] A luz cegante do relâmpago provoca a transmutação espiritual através da qual o homem adquire o poder da visão. (ELIADE, 1991, p. 13)
\end{abstract}

O próprio relato mítico cristão da criação ocorre com o ato primordial do divino iluminar as trevas, de dar forma ao informe, de dar ordem ao caos. Mais interessante ainda é observar que a divindade cristã não eliminou as trevas, somente a separou da luz: "No princípio Deus criou os ceús e a terra. Era a terra sem forma e vazia; trevas cobriam a face do abismo, e o Espírito de Deus se movia sobra a face das águas. Disse Deus: 'haja luz', e houve luz. Deus viu que a luz era boa, e separou a luz das trevas" (GÊNESIS, 2013, p. 04).

Sob o viés do trajeto antropológico de Durand (2012, p. 185), a necessidade de organização, de separação, de dar forma ao informe estaria no âmbito do regime diurno da representação da imagem. Durand (2012, p. 149) também reconheceu que a maior parte das religiões reconhecem o isomorfismo do celeste e do luminoso enquanto simbolismo de uma manifestação divina: "Os Upanixades, tão ricos em imagens da flecha e da ascensão rápida, estão realmente cheios de símbolos luminosos, Deus é aí chamado o "Brilhante", "Brilho e Luz de todas as luzes [...]".

O segundo painel, nomeado "O Sacrifício de Abraão", mede 12 metros quadrados, Zé Diabo levou aproximadamente um ano para concluí-lo. Feita a leitura do episódio no texto sagrado, primeiro foi concebido em uma maquete para que pudesse estudar a distribuição das figuras, formas, profundidade e proporções. O painel é composto por um anjo, um carneiro, Abraão e seu filho. O resultado é a expressão da interpretação do artista.

A imagem 2 representa o relato bíblico sobre a provação divina pela qual Abraão passou ao demonstrar que estava disposto a sacrificar seu próprio filho em obediência ao seu deus. A ideia de provação está arraigada em várias religiões e filosofias, como no cristianismo, budismo, judaísmo, islamismo, além de outras organizações sectárias, que indicam a necessidade do indivíduo passar por momentos de dificuldades e sofrimento para provar sua fidelidade à determinada doutrina ou demonstrar prontidão para receber determinadas responsabilidades e ensinamentos. Nesse tocante, Eliade (1978, p. 38) afirmou que "na aurora do Tempo, a divindade revelava a ciência secreta a determinados personagens, célebres pela sua devoção e pelas suas faculdades visionárias". 


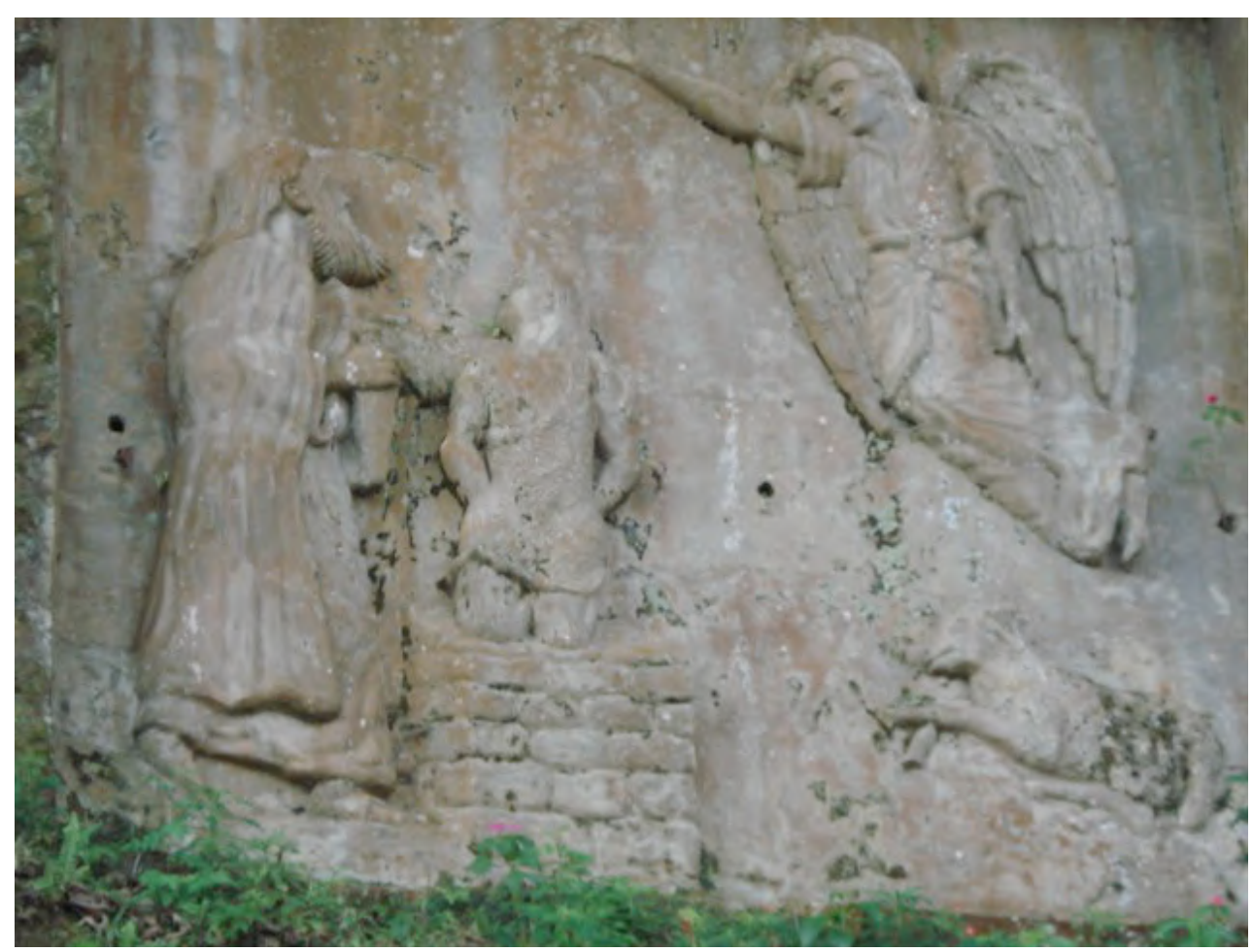

Imagem 2. Fonte: arquivo das autoras.

Nesse tocante, mesmo aquele que não está envolvido em uma organização religiosa ou filosófica tende a encontrar explicações para as dificuldades que encontra no seu viver na tentativa de eufemizar os aspectos não conhecidos que envolvem sua existência, suas frustrações ou anseios, de forma que pode, muitas vezes, em vez de transferir a responsabilidade de determinada circunstância e evento de seu viver a um deus, projetar suas angústias a determinado partido político, organização e até mesmo outra pessoa de seu convívio pessoal. No caso da imagem esculpida por Zé Diabo, a figura divina presente no imaginário cristão se mostra como regente dos acontecimentos sociais e individuais, o que dá sentimento de pertença, integração e segurança para determinado povo, nação ou sujeito.

O terceiro painel - imagem 3 - tem dimensões maiores que os primeiros. Medindo cinquenta metros quadrados, sua execução tomou dois anos de dedicação desde a concepção ao fim. Este recebeu o nome de "A Passagem do Mar Vermelho" e foi uma releitura do episódio bíblico de mesmo nome.

Nessa escultura Zé Diabo também materializa o relato bíblico em que a divindade exerce poder no mundo terreno, conduzindo os atos humanos na tentativa de livrar os judeus de exílios e do poder exercido contra eles por outros povos. Pode-se verificar que as imagens produzidas pelo artista buscam evidenciar o imaginário da presença do sagrado em determinado contexto social, aproximando-o do viver secular de determinado povo ou indivíduo e, portanto, sacralizando-o. 


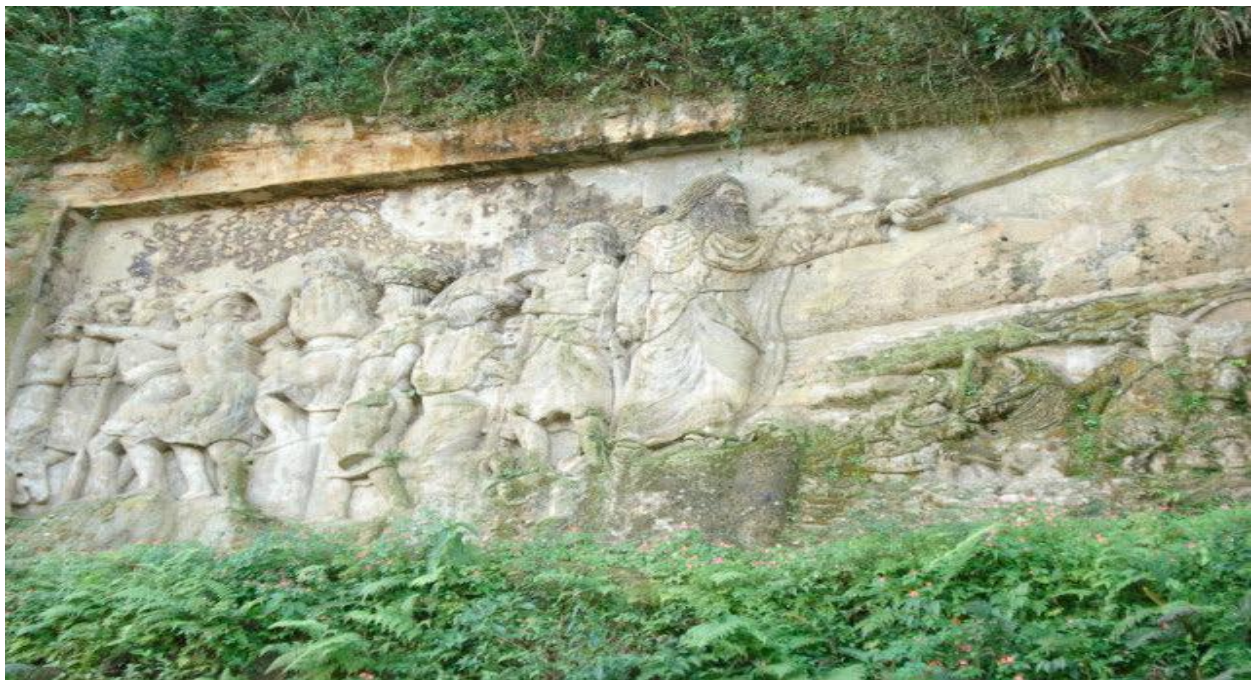

Imagem 3. Fonte: arquivo das autoras, 2017.

O outro painel de nome "O Templo do Rei Salomão" tem também cinquenta metros e levou um ano e meio para ser esculpido.

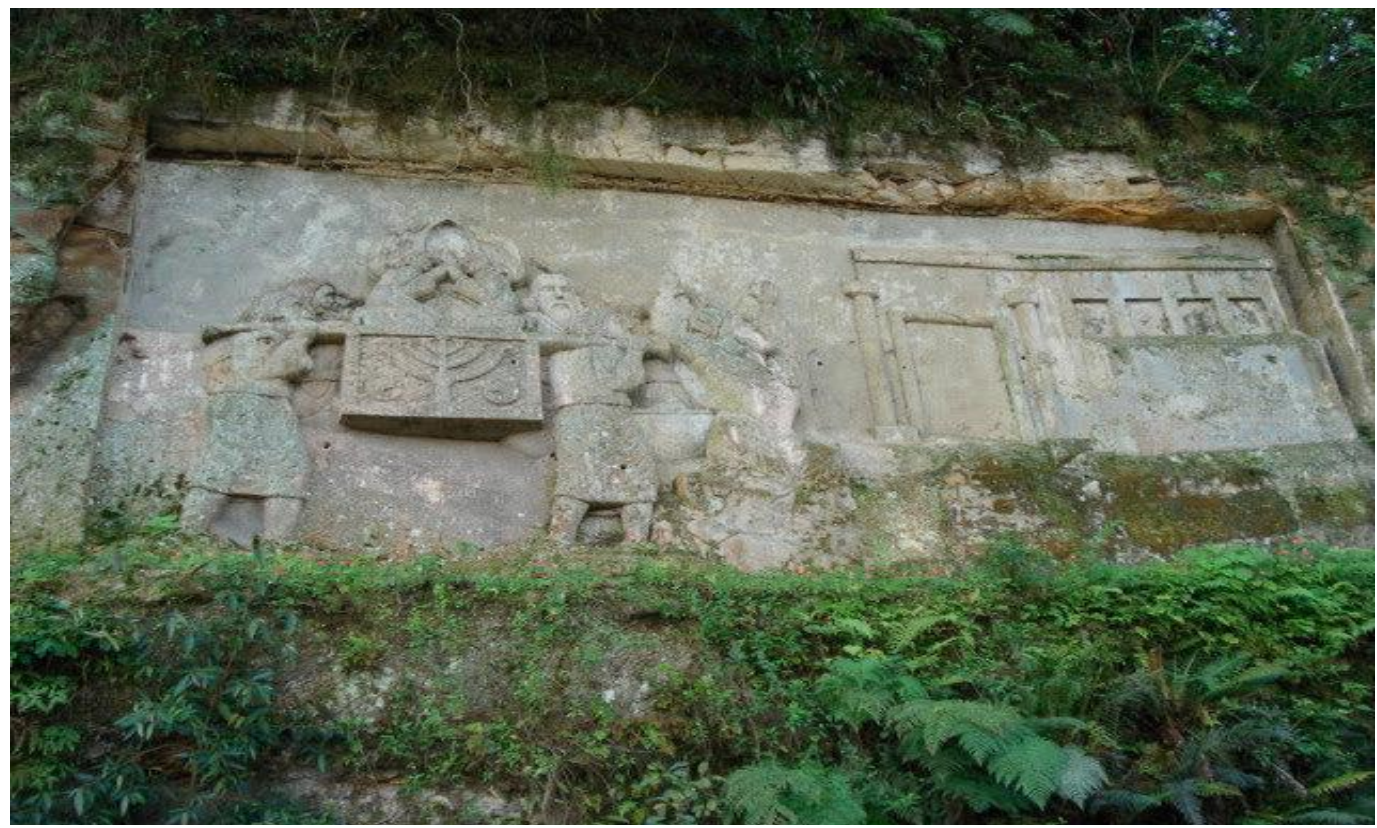

Imagem 4. Fonte: arquivo das autoras, 2017.

A imagem acima materializa o relato bíblico da construção do templo de Salomão. As escrituras bíblicas indicam que a construção teria sido ordenada pela própria divindade como promessa desta se manter presente entre seu povo. Para Eliade (1992), o templo constitui a inserção do sagrado em um espaço profano.

depois de tudo o que acabamos de dizer, é fácil compreender por que a igreja participa de um espaço totalmente diferente daquele das aglomerações humanas que a rodeiam. No interior do recinto sagrado, o mundo profano é transcendido. [...] Assim acontece em numerosas religiões: o templo constitui, por assim dizer, uma "abertura" para o alto 
e assegura a comunicação com o mundo dos deuses. (ELIADE, 1992, p. 40)

Para concluir a parte referente ao antigo testamento, a última cena esculpida nomeia-se "Os Profetas". Este possui vinte metros quadrados e traz os últimos profetas do antigo testamento, Isaías e Malaquias, que marcam a transição às releituras do novo testamento.

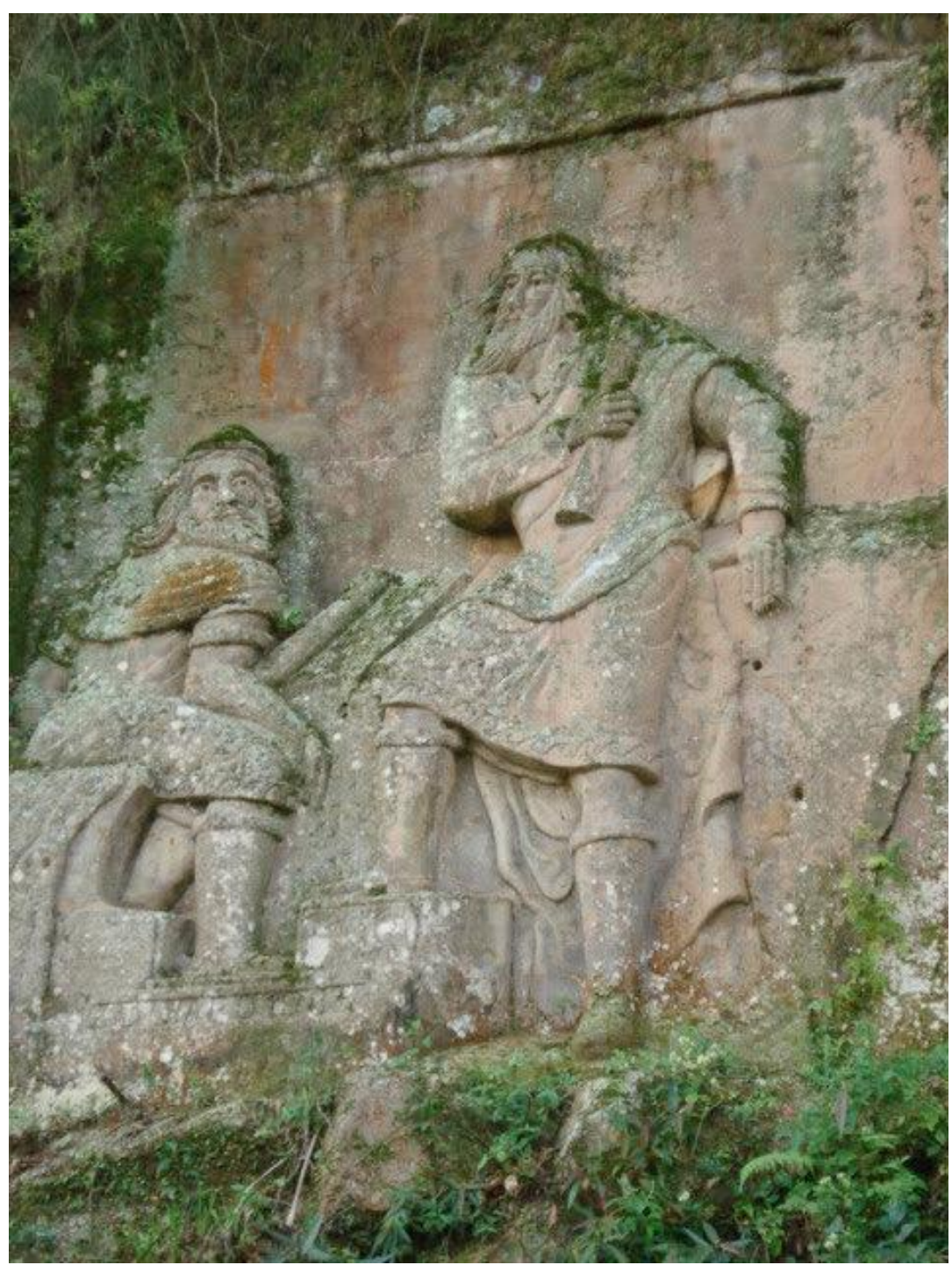

Imagem 5. Fonte: arquivo das autoras, 2017.

Os profetas nas narrativas bíblicas tinham a função de disseminar os ensinamentos divinos, levar adiante a mensagem recebida e disseminar a existência do sagrado. Podese verificar nos escritos bíblicos que a força da imagem enquanto representação do sagrado não era bem vista, principalmente nos relatos do antigo testamento, enquanto a escritura tinha sua supremacia na relação com a divindade. A maior prova disso foi a importância dada às tábuas dos dez mandamentos entregues a Moisés e a escrituração dos ensinamentos de Jesus Cristo nos evangelhos, cujo papel dos profetas foram fundamentais para o registro da existência do referido mestre. Para Wunenburguer, 
essas diferenciações entre imaginários visual e linguístico dão origem a reforços normativos nas diferentes tradições culturais. [...] O judaísmo valoriza antes de tudo uma cultura da linguagem que chega a condenar a imagem material por sua propensão a conduzir os homens à idolatria, à confusão entre a imagem e o ser divino. [...] A pintura tem sobre a literatura a vantagem de se prestar a um devaneio mais espontâneo, menos condicionado pela cultura letrada. Por isso, a imagem visual enriquece mais o imaginário individual ou coletivo do que os atos e as obras da linguagem. (WUNENBURGER, 2007, p. 29)

Por isso a importância das esculturas do artista, pois a imagem enquanto registro de determinada narrativa traz para esfera material o que é refratário ao conceito, aquilo que tem de ser vivido em todas as suas nuances - pois quanto mais sentidos são utilizados para vivenciar o sagrado, mais aquela vivência se registra no imaginário individual e coletivo, por isso a utilização de vários recursos simbólicos, sonoros e visuais em igrejas e demais organizações filosóficas e sectárias.

Já o primeiro painel produzido pelo artista Zé Diabo a expressar imagens do novo testamento chama-se "A Anunciação" e possui vinte metros quadrados. Enquanto executava o painel anterior, o artista relatou que a imagem da anunciação surgiu de inspiração súbita e que, para não perder a concepção, foi se guiando numa coluna que há no paredão e desenhou um anjo pequeno da anunciação na pedra, que era para não perder a criatividade e que Nossa Senhora já foi esculpida como se vê nos dias atuais.

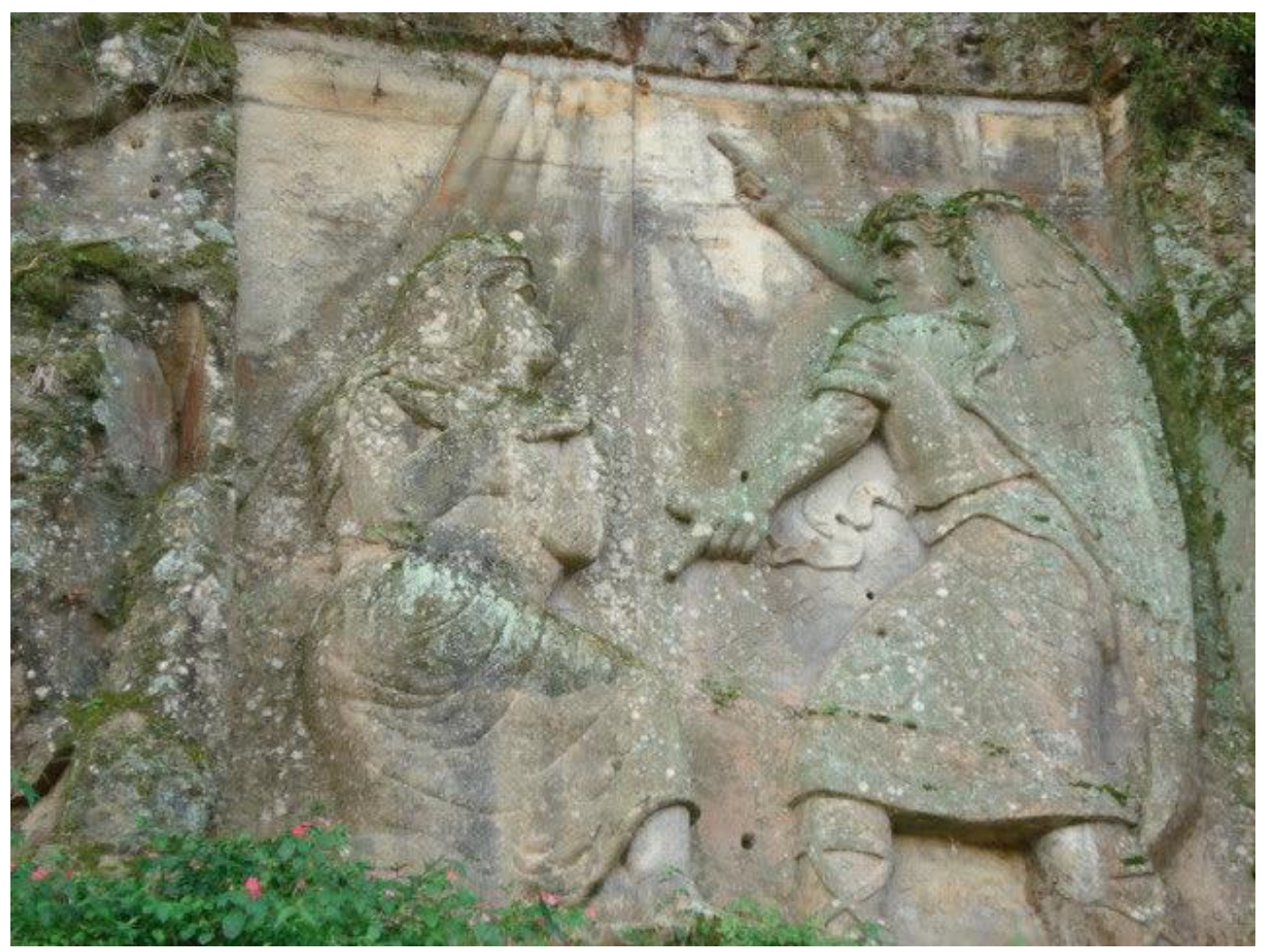

Imagem 6. Fonte: arquivo das autoras, 2017.

Essa inspiração súbita que pela qual o artista relata ter sido acometido pode ser considerada a imaginação criadora, que se trata de uma imaginação transcendental, com um poder inerente de produzir novas imagens e de as recombinar em forma proto-imagens 
de que a "metáfora viva", o símbolo e o mito constituem exemplos (RICOEUR apud ARAÚJO; ALVERNE, 2017, p. 8).

O último painel "Nascimento de Jesus". De dimensões semelhantes ao anterior, revela a concepção do artista sobre o nascimento de Jesus e os tributos e honrarias que recebeu dos magos do Oriente.

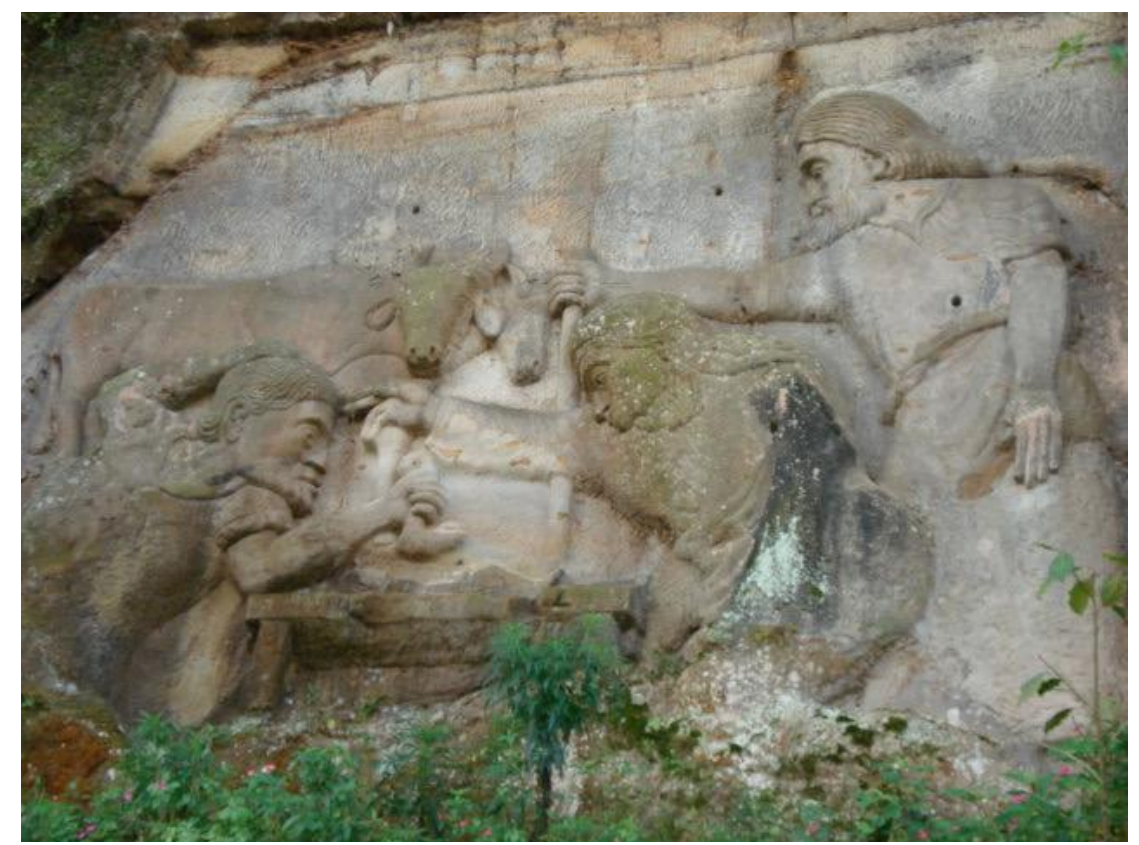

Imagem 7. Fonte: arquivo das autoras, 2017.

As obras produzidas por Zé Diabo traduzem sua subjetividade, sua relação com o sagrado, manifestam o seu imaginário do sagrado e contribuem para lapidar o imaginário coletivo da cidade de Orleans, pois nas palavras de Wunenburguer,

o imaginário das obras mostra-se assim como um espaço de realização, de fixação e de expansão da subjetividade. Mas, por intermédio dessa representação, o artista visa algumas imagens novas, que por sua vez farão parte da subjetividade de cada um. As obras de arte permitem a transmissão e o compartilhamento do vivido, do sentir, do ver, e assim tornam possível uma participação num mundo comum. $\mathrm{O}$ imaginário artístico, por exteriorizar a subjetividade, favorece uma relação intersubjetiva. Por outro lado, a experiência de recepção com as imagens artísticas atinge cada um em vários níveis; algumas obras se limitam a espetáculos, permitindo suspender o aspecto sério, abrir territórios de jogo (teatro, cinema, música); em outros casos, o vivido espetacular é dobrado por uma interiorização espiritual, as imagens nutrindo o pensamento. (WUNENBURGER, 2007, p. 58)

Através da arte - em qualquer de suas manifestações -, o indivíduo tem a possiblidade de se (re)conectar ao sagrado, de fazer o imanente alcançar o transcendente e assim perenizar sua singularidade na exterioridade, seja no lapidar de rochas, na escritura de um texto, na harmonização de sons em uma música ou na simples contemplação de qualquer coisa exterior a si mesmo. 
Sem verbas para terminar as projeções feitas pelo artista, a obra foi interrompida, mas Zé Diabo continuou executando outras obras sacras, recriando, inclusive, a técnica em baixo relevo, muito utilizado pelos mesopotâmicos e egípcios. Utilizando cimento, espátula e criatividade, o escultor deixou registrada a história, em várias Igrejas e capelas da região sul, imortalizando sua crença nas obras que são a expressão de sua religiosidade.

\section{O SIMBÓLICO NO SAGRADO}

As imagens e os símbolos constituem-se para o homem aberturas sobre um mundo de significações mais abrangentes do que aquele em que ele vive. Os objetos do mundo e os atos humanos não teriam valor por si só, eles adquirem valor quando participam de uma realidade que os transcendem. Dessa forma, o ser ou um objeto se diferencia do seu meio porque surge como um receptáculo de uma força exterior que lhe dá significado e valor (ELIADE, 1952, p. 13).

As imagens esculpidas por Zé Diabo no paredão de pedras brutas que costeiam as margens do rio Tubarão, registram as passagens bíblicas, indicando acontecimentos que apresentavam influência de uma hierofania, pois os atos humanos e sociais descritos em tais narrativas eram regidos, estimulados e mensurados pelo poder divino e, por isso a importância e relevância de registrá-los, seja na forma escrita ou na forma de imagens esculpidas.

É interessante observar o padrão intrínseco nas passagens bíblicas esculpidas por Zé Diabo. Segundo as narrativas, a divindade exerce poder no mundo terreno, conduzindo os atos humanos na tentativa de livrar os judeus de exílios e do poder exercido contra eles por outros povos. Essa relação com a divindade normalmente era realizada por intermédio dos profetas e sacerdotes, os quais, após contato direto com o divino, faziam cumprir a orientação então recebida, o que ocorreu, por exemplo, na passagem dos judeus pelo Mar Vermelho após serem libertos da escravidão a que estavam expostos no Egito, ação essa liderada pelo profeta Moisés (VAN LOON, 1951, p. 97). O meio social sofre, então, constantes transformações em razão da vontade divina, a qual passa a fazer parte do cotidiano daquele povo.

[...] Desde o começo o estado judeu havia sido uma teocracia, isto é, um país regulado por um "theos" ou deus. Como nesses casos o deus não pode residir na terra, ele dirige seus domínios por meio duma classe de sacerdotes profissionais, intérpretes de sua vontade por meio da interpretação de sonhos e certos sinais da natureza. O "theos", seja ele Jeová ou Júpiter, tem que permanecer invisível à massa do povo. Em consequência, os sacerdotes se tornam os seus representantes na terra e os executantes de sua vontade. Um poder mais ou menos semelhante ao do vice-rei das Índias, que governa centenas de milhões de súditos em nome do distante e misterioso Imperador residente no palácio Buckingham, em Londres e nunca é visto pelos habitantes de Calcutá e Bombaim. (VAN LOON, 1951, p. 97)

A imortalização da crença, por meio de imagens, mitos e símbolos faz com que ela seja registrada e não só seja acessada sempre que possível, mas que passe então a reger o imaginário de determinada sociedade. Isso porque, Durand (2001, p. 6) afirma que "o imaginário se configura como 'o museu de todas as imagens passadas, possíveis, produzidas e a serem produzidas'. Para Moraes, 
há um fio condutor que liga o imaginário da humanidade, já que é possível verificar as mesmas imagens e estruturas afetivas se manifestarem, ainda que simbolicamente atualizadas no espaço e no tempo. Ao estudarmos o imaginário, podemos refletir sobre o dinamismo da vida e suas manifestações culturais. Podemos encontrar relação entre as narrativas das antigas mitologias com as materialidades culturais (e midiáticas) da atualidade. Os símbolos e os mitos se repetem através do tempo. (MORAES, 2016, p. 138)

A palavra imagem e imaginação estão profundamente relacionadas, pois, segundo Eliade (1952, p. 20), imaginação tem sua origem na palavra latina imago, (que significa representação, imitação) e também na palavra imitor, que significa imitar, reproduzir. A imaginação imita modelos exemplares, que seriam as imagens, e tem o poder de apresentar tudo aquilo que permanece refratário ao conceito. "Assim se explica a desgraça e a ruína do homem que não tem imaginação: ele está isolado da realidade profunda da vida e da sua própria alma" (ELIADE, 1952, p. 20).

Nas esculturas que produziu, Zé Diabo imortaliza a íntima ligação do homem com o Deus que o criou. Isso porque a escultura responsável por retratar a criação do homem é um ato que por si só revela a necessidade do humano conhecer sua origem, de se sentir ligado ao universo e compreender sua atuação no mundo. Não há quem nunca tenha se perguntado como veio ao mundo, qual foi a origem do ser humano neste planeta repleto de outras espécies, qual o verdadeiro propósito da vida e o que seria isso que se chama de vida. Estamos aí no campo da função mitológica. Segundo Almeida,

o mito fornece os sentidos necessários para o homem se situar no mundo, é a base das produções simbólicas do imaginário. É a potência criadora e mediadora da vida individual e coletiva, está na base das atividades psíquicas, das narrativas biográficas, rege a vida social, as formulações ideológicas, as narrativas históricas. (ALMEIDA, 2011, p. 23)

Verifica-se, assim, a importância do mito, pois é por meio dele que se encontra uma resposta para as indagações existenciais que carecem de comprovação científica. Os relatos bíblicos são, por sua vez, mitos, pois segundo Vaz (2003, p. 410-411), em seu estudo sobre o Gênesis bíblico, são "narrações imaginárias, portadoras de significações figuradas". É o mito que rege a vida individual e coletiva, é ele que permite que se tenha um porquê de se levantar todos os dias e se dar continuidade à empreitada humana no orbe terrenal. Por isso, Eliade (1952, p. 14) indica a necessidade de o homem moderno ter contato com as imagens e símbolos, pois ali ele encontraria, nas suas palavras, o seu "paraíso perdido":

quando um ser historicamente condicionado, por exemplo, um ocidental dos nossos dias, se deixa invadir pela parte não histórica de si próprio (o que lhe acontece com muito mais frequência e muito mais radicalmente do que ele imagina), não é necessariamente para regredir ao estágio animal da humanidade, para tornar a descer às fontes mais profundas da vida orgânica: imensas vezes ele reintegra, pelas imagens e símbolos que põe em marcha, um estágio paradisíaco do homem primordial (seja como for a existência concreta daquele, pois este homem primordial afirma-se sobretudo como um arquétipo impossível de realizar em qualquer existência humana). Fugindo à sua historicidade o homem não abdica da sua qualidade de ser humano para 
se perder na animalidade; ele reencontra a linguagem e por vezes a experiência de um paraíso perdido. Os sonhos, os sonhos acordados, as imagens das suas nostalgias, dos seus desejos, dos seus entusiasmos, etc., são outras tantas forças que projetam o ser humano historicamente condicionado num mundo espiritual infinitamente mais rico do que o mundo fechado do seu momento histórico. (ELIADE, 1952, p. 14)

Por meio das imagens, arquétipos e símbolos, o mito, como narrativa, leva o ser humano a uma realidade que transcende o seu viver puramente material. Faz com que esteja profundamente ligado à sua esfera divina, àquela ilustrada pelos relatos bíblicos nas narrativas transformadas em esculturas por Zé Diabo. Para Eliade (1952, p. 169), as imagens são como portais para um mundo "trans-histórico" e é em razão delas que diversas histórias podem comunicar, inclusive a do homem moderno com aquele que outrora teria tido o contato direto com a divindade, como é o caso das narrativas do antigo testamento.

Sobre essa interação entre imagens e símbolos, assim como a relação deles com a religião e a arte, Jung afirma:

com sua propensão para criar símbolos, o homem transforma inconscientemente objetos ou formas em símbolos (conferindo-lhes assim enorme importância psicológica) e lhes dá expressão, tanto na religião quanto nas artes visuais. A interligada história da religião e da arte, que remonta aos tempos pré-históricos, é o registro deixado por nossos antepassados dos símbolos que tiveram especial significação para eles e que, de alguma forma, os emocionaram. Mesmo hoje em dia, como mostram a pintura e a escultura modernas, continua a existir viva interação entre religião e arte. (JUNG, 1964, p. 227)

Através de suas esculturas, Zé Diabo calcou suas crenças no paredão de pedras de Orleans, não só materializou aquilo que explicava o seu mundo, mas também se materializou por meio de sua singularidade deixada em suas obras. Isso porque, para Heidegger (1977, p. 3), a obra de arte surge através do artista e o artista através da obra de arte, de forma que um não é sem o outro.

Segundo a compreensão normal, a obra surge a partir e através da atividade [sic] do artista. Mas por meio e a partir de quê é o artista é o que é? Através da obra; pois é pela obra que se conhece o artista, ou seja: a obra é que primeiro faz aparecer o artista como um mestre da arte. O artista é a origem da obra. A obra é a origem do artista. Nenhum é sem o outro. E, todavia, nenhum dos dois se sustenta isoladamente. Artista e obra são, em si mesmos, e na sua relação recíproca, graças a um terceiro, que é o primeiro, a saber, graças àquilo a que o artista e a obra de arte vão buscar o seu nome, graças à arte. (HEIDEGGER, 1977, p. 3)

A partir do momento que Zé Diabo imortalizou sua crença na obra de arte, este também se imortalizou, deixando sua singularidade indelével sobre o paredão de pedra, pois mesmo que outra pessoa tentasse reproduzir as mesmas narrativas, nas mesmas pedras, com os mesmos instrumentos, muito provavelmente as esculturas se mostrariam diferentes. Ainda, sobre o conteúdo da obra de arte, Heidegger (1977, p. 13) afirma que "a obra dá publicamente a conhecer outra coisa, revela-nos outra coisa; ela é alegoria. À coisa fabricada reúne-se ainda, na obra de arte, algo de outro. [...] A obra é símbolo". 
Da mesma forma, as obras produzidas por Zé Diabo, teriam uma função simbólica, pois, nas palavras de Pitta (2005, p. 18), símbolo é um signo que evoca algo que está ausente e é responsável por representar, fazer aparecer, um sentido que não está manifesto. As esculturas produzidas por Zé Diabo evocam a outrora presença divina vivenciada por um povo, em um espaço-tempo em que a divindade e sua criação andariam pari passu, unidas por aquilo que Heidegger (1977, p. 3) afirmou sobre o artista e a obra de arte: "um não é sem o outro", pois ainda que a dualidade pareça não descrever a realidade da melhor forma, parece certo afirmar que o sagrado parece existir somente em razão da existência do profano. Conforme as palavras de Eliade (1952, p. 13), dentre tantas pedras, uma torna-se sagrada, porque ela é uma hierofania, ela manifesta algo que está além do conhecimento convencionado.

\section{CONSIDERAÇÕES FINAIS}

Os fatos religiosos são alguns dos mais antigos na partilha das articulações do real e do imaginário, dando sentido a certas práticas do cotidiano, sejam prescrições alimentares ou ritualísticas (como a comunhão da hóstia, o jejum ou a abstinência de algum alimento), sejam fatos meteorológicos (crença em castigos impostos por Deus, como o dilúvio ou uma epidemia), sejam representações simbólicas (narrativas míticas ou bíblicas), ainda, textos de leis, como os Dez Mandamentos ou textos exemplares como o Evangelho ou as regras do catecismo.

A religião, qualquer que seja seu rito, articula fatos reais, simbólicos e imagens porque repousa sobre crenças que sustentam a singularidade do imaginário de cada um que nelas crê, ao mesmo tempo que promove o sentimento de pertença frente à coletividade que adere à crença. A religião configura, desse modo, uma linguagem, porque torna interpretável, para todos os que nela creem ou que a ela aderem, o real e todo o simbolismo que estruturam a existência e são mobilizam para expressar uma significação, na perspectiva do imaginário. Nesse estudo, tratamos de uma linguagem não- verbal rica em expressividade e sentido.

A arte pode ser também o exercício do sagrado, pois neste jogo do simbólico que as imagens esculpidas na rocha (re)velam fazem parte do patrimônio de dada comunidade, pois

a ideia de posse coletiva como parte do exercício da cidadania inspirou a utilização do termo patrimônio para designar o conjunto de bens de valor cultural que passaram a ser propriedade da nação, ou seja, do conjunto de todos os cidadãos. A construção do que chamamos de patrimônio histórico e artístico nacional partiu, portanto, de uma motivação prática - o novo estatuto de propriedade de bens confiscados - e de uma motivação ideológica - a necessidade de ressemantizar esses bens. (FONSECA, 1997, p. 58)

Pensando sobre essa posse da coletividade, podemos compreender que as esculturas do paredão em Orleans-SC são espaços sagrados e se caracterizam por lugares de manifestações do sagrado. A arte sacra evoca o divino, aquilo que transcende o conceito espaço-tempo, materializando-se por meio da beleza visível e a ser contemplada, busca expressar o mistério invisível, não como cópia fiel nem como fotografia, mas sim como representação simbólica. 


\section{REFERÊNCIAS}

ALMEIDA, R. Mitocrítica e mitanálise no campo da hermenêutica simbólica. Em: GOMES, E.S.L. Em busca do mito: a mitocrítica como método de investigação do imaginário. João Pessoa: Editora Uda UFPB, 2011.

ARAÚJO, A.F.; ALVERNE, I.M. Educar para a Imaginação. Revista Memorare, Tubarão, v. 4, n. 2, 73-105, maio/ago. 2017.2 Disponível em: http://www.portaldeperiodicos.unisul.br/index.php/memorare grupep/article/view/5230/3219.

Acesso em 30 abr. 2018.

ARISTÓTELES. Poética. Trad. Bras. São Paulo: Difusão Europeia do Livro, 1959.

AZEVEDO JUNIOR, J.G. de. Apostila de Arte - artes visuais. São Luís: Imagética Comunicação e Design, 2007.

CAMPBELL, Joseph. As máscaras de deus: mitologia criativa. São Paulo: Palas Athena, 2010. DURAND, Gilbert. As estruturas antropológicas do imaginário; introdução à arquetipologia geral. Trad. Bras. São Paulo: Martins Fontes, 2012.

. O imaginário. Trad. Bras. 2a . ed. Rio de Janeiro: Difel, 2001.

. Campos do imaginário. Textos reunidos por Danièle Chauvin. Grenoble: Ellug, 1996.

ELIADE, M. Mito do eterno retorno. São Paulo: Mercuryo, 1992.

O sagrado e o profano. São Paulo: Martins Fontes, 1992.

. Mefistófeles e o Andrógino. São Paulo: Martins Fontes, 1991.

. História das crenças e das ideias religiosas: de gautama buda ao triunfo do cristianismo.

2a. ed. Rio de Janeiro: Zahar, 1978.

. Imagens e símbolos. São Paulo: Arcádia, 1952.

FISCHER, E. A necessidade da arte. Rio de Janeiro: Zahar, 1983.

FONSECA, M.C.L. O patrimônio em processo: trajetória da política federal de preservação no Brasil. Rio de Janeiro: Editora UFRJ, 1997.

GALLINA, F.S.; ORMEZZANO, G.R. Educação estética e imaginário numa jornada arquetípica.

Revista Memorare, [S.1.], v. 4, n. 3, 253-277, nov. 2017. Disponível em: http://portaldeperiodicos.unisul.br/index.php/memorare grupep/article/view/5665/3399. Acesso em 13 dez. 2017.

GÊNESIS. Bíblia de estudo arqueológica. Trad. Bras. São Paulo: Vida, 2013.

HEIDEGGER, M. A origem da obra de arte. Lisboa: Edições 70, 1977.

LEAL, Z.S.; LINS, E.S. Telejornalismo e imaginário: uma análise mitocritica da transposição do "velho chico". REVISTA MEMORARE, [S.1.], v. 4, n. 2-I, 41-62, ago. 2017. Disponível em: http://portaldeperiodicos.unisul.br/index.php/memorare grupep/article/view/5174. Acesso em 13 dez. 2017.

MORAES, H.J.P. Sob a perspectiva do imaginário: os mitos como categoria dos estudos da cultura e da mídia. Em: FLORES, G.B.; NECKEL, N.R.M.; GALLO, S.M.L. Análise do discurso em rede: cultura e mídia. São Paulo: Pontes, 2016. p. 137-177.

; BRESSAN, L.I. Bacia semântica e o trajeto antropológico em uma narrativa históricoliterária sobre imigração italiana: marcas de ancestralidade. Revista Alere, Cuiabá, v. 15, n. 01, 135-157, jul. 2017.

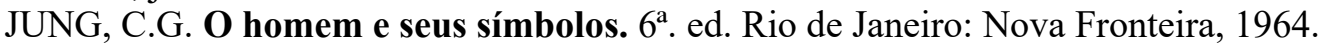

PANOSFSKY, Erwin. Significado nas artes visuais. 2a ed. São Paulo: Perspectiva, 1979.

PITTA, D.P.R. Iniciação à teoria do imaginário de Gilbert Durand. Rio de Janeiro: Atlântica Editora, 2005.

QUADROS, A. Estruturas simbólicas do imaginário na literatura portuguesa. Lisboa: Átrio, 1992.

RICOUER, Paul. Hermenêutica e ideologias. $3^{\mathrm{a}}$. ed. Rio de Janeiro, Vozes, 2013.

Do texto à ação. Porto: Rés-Editora, 1991.

Teoria da interpretação: o discurso e o excesso de significação. Trad. Bras. Lisboa: Edições 70, 1976.

SILVA, E.T. da; GOMES, E.S.L. Hermenêutica simbólica e filosofia do símbolo. Reflexus, Vitória, v. $7, \quad$ n. $9, \quad 125-142, \quad 2013 . \quad$ Disponível em http://revista.faculdadeunida.com.br/index.php/reflexus/article/view/194. Acesso em 14 dez. 2017. 
VAN LOON, H.W. A história da Bíblia. Trad. Bras. São Paulo: Cultrix, 1951.

VAZ, A. dos Santos. As forças das imagens nas narrativas bíblicas da criação. Em: ARAUJO, A.F.; BAPTISTA, F.P. Variações sobre o imaginário: domínios, teorizações e práticas hermenêuticas. Lisboa: Instituto Piaget, 2003. p. 409-456.

WUNENBURGER, Jean-Jacques. O imaginário. São Paulo: Loyola, 2007.

Artigo recebido em: março de 2018.

Aprovado e revisado em: agosto de 2018.

Publicado em: dezembro de 2018.

Para citar este texto:

MORAES, Heloisa Juncklaus Preis; BRESSAN, Luiza Liene; FERNANDES, Ana Caroline Voltolini. O imaginário do sagrado a partir das Esculturas do Paredão em Orleans-SC: a arte do sagrado e o sagrado na arte de Zé Diabo. Entremeios [Revista de Estudos do Discurso, ISSN 2179-3514, on-line, www.entremeios.inf.br], Seção Temática [Discurso, arte e literatura - Parte II], Programa de Pós-Graduação em Ciências da Linguagem (PPGCL), Universidade do Vale do Sapucaí (UNIVÁS), Pouso Alegre (MG), vol. 17, p. 199-217, jul. - dez. 2018. DOI: http://dx.doi.org/10.20337/ISSN2179-3514revistaENTREMEIOSvol17pagina199a217 